\title{
1. Gone with hardly a trace: deportees in immigration policy
}

\author{
Glenn Nicholls
}

In 1910, Winston Churchill, the British Home Secretary, sought information on deportation practices in order to coordinate them across the empire. J. A. Stalking, Acting Secretary of Australia's Department of External Affairs, made a note on Churchill's letter, indicating that the matter was of marginal relevance to Australia and would become important only 'should our present powers of deportation be increased by legislation or more extensively availed of in practice' . $^{1}$

This note was remarkable for completely ignoring the extensive use that the Australian Government had made of deportation since Federation. Just two years earlier, in 1908, the government had concluded a mass deportation campaign against Pacific Islanders, the basis for which was laid in one of the first acts passed by the Commonwealth Parliament, the Pacific Island Labourers Act 1901. Under the act, more than 4000 Islanders were deported, mainly to the New Hebrides, Solomon Islands and Fiji. The Commonwealth Government's power to do this was challenged in the first deportation case heard by the High Court, Robtelmes vs Brenan (1906). The challenge was unanimously dismissed and the Commonwealth's deportation power established in resounding terms. In a statement almost prescient of John Howard's 2001 election slogan, 'We will decide who comes to this country and the circumstances in which they come', Chief Justice Samuel Griffith declared that the Commonwealth had untrammelled power 'to determine the conditions under which aliens may be admitted to the country, the conditions under which they may be permitted to remain in the country, and the conditions under which they may be deported from it'. ${ }^{2}$

This chapter argues that those formulating Australian deportation policy have consistently failed to learn from the past. This is because deportation decisions have been driven by policy imperatives such as national security and immigration control, rather than focusing on whether or not individuals should be deported. Immigration policy makers in particular have seen themselves as being responsible for managing incoming migration; from this perspective, deportation is simply a consequence of someone not being entitled to stay in the country. No lasting policy has been developed to take individuals' circumstances into account or to examine factors militating against deportation. 
When called on to justify deportations, policy makers have invoked their duty to uphold national security, law and order or immigration controls and have portrayed deportees as a group who abuse Australia's hospitality by overstaying their welcome, committing crimes or being associated with Australia's enemies (whether by choice or not). After World War I, the backbencher John Leckie justified his government's deportation of more than 6000 German-Australians with the claim that 'they were unworthy of Australia's hospitality', although many were long-term residents of the country and were given no opportunity to put their case to stay. ${ }^{3}$

The mass deportation program after World War I followed large scale internment (see Chapter 4 of this volume) and has rightly been called 'the destruction of the German-Australian community' at that time. ${ }^{4}$ Deportation frequently removes not only the people concerned but traces of their pasts in the country - an erasure that facilitates forgetting. There are no public memorials to deported peoples in Australia and few works of art on the theme - an exception is a 1991 novel by Joan Dugdale, which is fittingly called Struggle of Memory, about a German-Australian family after World War I. ${ }^{5}$ The former presence of deported individuals and groups is often retrieved from obscurity only later. This chapter examines various examples from the past, but also endeavours to analyse current deportation policy in this light. It argues that current policy misses opportunities for positive change that could be gleaned from past knowledge and experience. Deportation policy today turns a blind eye to the personal histories of individuals facing deportation and also to the knowledge built up by courts, tribunals and officials who have dealt with deportation cases in previous decades.

\section{Activism against deportation by Pacific Islanders}

The Pacific Islander episode provides an instructive first example because the Islanders briefly managed to make their cause a prominent concern for Australia's politicians and achieved changes in government policy. In 1905 and 1906, with the deadline for deportation looming at the end of 1906, Islanders launched energetic protests, although their weak legal position had been confirmed by the Robtelmes case. They succeeded in being granted an audience with Prime Minister, Alfred Deakin, and eventually won important exemptions from deportation for people who were long-time residents of Australia, were too old or infirm to travel, had locally born spouses or children or who had a spouse from another island, which was thought to make the prospect of return fraught with conflict. These exemptions allowed 2500 Islanders to stay in the country legally. An estimated further 1000 stayed unlawfully but lastingly since staying on was easier amid a sizeable remnant community. ${ }^{6}$ These concessions did not, however, become part of any developed deportation policy. Neither did the fact that a community of Islanders remained in Australia after the deportation program began command any attention in government policy. These were the 'forgotten 
people', as historians Clive Moore and Patricia Mercer wrote in $1978 .^{7}$ In 1993 , the Keating Labor Government asked the Human Rights and Equal Opportunity Commission to collect statistics on the community, since not even the number of people who identified as Islanders was known. ${ }^{8}$

At the time of the Islanders' deportation, Senator Henry Dobson criticised his colleagues in Parliament for learning nothing from the mistake of legislating for the wholesale removal of Pacific Islanders in 1901. Speaking in December 1905 as Islanders were mounting their protests, Dobson stated that in the Pacific Island Labourers Act 1901 'we absolutely ignored the principles of humanity and Christianity. We made no provisions for exceptions. ${ }^{9}$ He argued that Parliament was making the same mistake again in 1905 when amending the Immigration Restriction Act 1901. The amendments tightened restrictions on Chinese immigrants and made no allowance for individuals who had made their homes in Australia, or had left the country intending to return but now found their re-entry blocked.

The exemptions won by Islanders represented an acknowledgment that the mass deportation program against them was unjust, but afterwards the same blanket measures came to be applied again - for example, against people who were deemed to be enemy aliens, or unsuitable or unauthorised immigrants, or who had overstayed their period of allowed residence. Time and again, groups and individuals resisting deportation from Australia have raised the same arguments in their defence: their commitment to their country of residence, length of residence, compassionate circumstances and the perils that exist in the destination state. Sometimes governments have accepted these arguments and exempted individuals or groups from deportation, only to forget the exemption categories immediately afterwards, so that later groups have to argue again for the same exemption categories from scratch. Governments have established firm criteria to select immigrants for settlement, but have been reluctant to lay down lasting criteria exempting people from the threat of deportation.

\section{Immigration control and deportation}

The Department of Immigration was created in 1945. As its first minister, Arthur Calwell gave no quarter to individuals resisting deportation. He was committed to building up a system for controlled immigration within the parameters of the White Australia Policy and enforcing the departure of prohibited immigrants. He maintained an uncompromising position on deportations. As Gwenda Tavan explains, Calwell believed that allowing people to avoid deportation on the basis of their individual circumstances 'would threaten the whole administrative apparatus upon which effective immigration control depended' ${ }^{10}$

In October 1948, Calwell introduced the Aliens Deportation Bill into Parliament. It established a specific process for the deportation of non-British aliens regardless 
of their length of residence in the country. Calwell explained that it targeted 'those aliens whose character and conduct is such that they should not be allowed to continue to reside here'. There was criticism in Parliament about the breadth of powers conferred by the act, but the only amendments accepted by the government were technical and the Act came into force on 18 January $1949 .{ }^{11}$ Calwell stated that the act was the first time that a law on deportation had been made using the aliens power of the Commonwealth Constitution rather than the immigration power. This was incorrect: it again overlooked the Pacific Islanders. As we saw earlier, the High Court rejected the Islanders' legal challenge to deportation with reference to the Commonwealth's power over aliens.

Shortly after seeing the Aliens Deportation Act 1948 come into force, Calwell had to deal with a threat to his deportation powers on another front, involving one of the few occasions in which the High Court found against the Commonwealth in a deportation case. In O'Keefe vs Calwell (1948), the court quashed a deportation order against Annie O'Keefe, a wartime evacuee from Indonesia who had married a local man. This was because she had not been formally given the status of a prohibited immigrant when she was allowed to enter Australia with a certificate of exemption, so the expiration of the certificate did not make her liable to deportation as a prohibited immigrant. Nor could she be declared a prohibited immigrant more than five years after being allowed into the country. The decision threatened Calwell's determination to force the departure from Australia of non-Europeans who had been allowed into the country during World War II. Although most such arrivals departed Australia voluntarily after the war ended, approximately 800 sought to stay permanently and at the time of the O'Keefe decision there were a number of similar cases either before the courts or being debated in public. ${ }^{12}$ In an infamous speech, Calwell claimed that the O'Keefe case opened the floodgates to a 'mongrel Australia' ${ }^{13}$

After the $O^{\prime}$ Keefe decision, Calwell moved to not only restore but strengthen the Commonwealth's deportation powers further. First, he amended provisions in the Immigration Act to overcome the procedural problems exposed by the court's decision. The original draft of this amendment was breathtakingly broad, giving the minister the power to deport anyone who had entered Australia after 1901. Legal counsel advised that the very breadth of the draft made it vulnerable to legal challenge and the amendment was pared back to apply specifically to certificates of exemption. $^{14}$ Henceforth these would be valid even if the individual concerned had not formally been given the status of a prohibited immigrant when he or she entered the country. This amendment restored the situation that the cancellation or expiration of certificates of exemption led to deportation.

In addition to this amendment, Calwell introduced the War-Time Refugees Removal Bill 1949, which was designed specifically to enable the deportation of 
every person who, as in the O'Keefe situation, had arrived in Australia during World War II and stayed afterwards without being an approved immigrant. The Act came into force on 12 July 1949 and empowered the minister to force any person to depart the country who had been allowed to enter as a result of the war and had not since left.

The success of Calwell's moves in shoring up and strengthening the Commonwealth's deportation powers was seen in the next deportation case before the High Court, Koon Wing Lau vs Calwell. This involved 43 individuals from Hong Kong who had been granted entry to Australia during the war and who fought deportation after Calwell's legislative changes. They argued that the changes were not a valid exercise of the Commonwealth's power. The court dismissed their appeal. Chief Justice John Latham was most emphatic in upholding the government's powers. He found that the Commonwealth could make laws providing for deportation for any reason it thought fit. He gave an array of criteria that the Commonwealth could use to order deportations and then added a catch-all to dispel any doubt: 'age, sex, race, nationality, personal character, occupation, time of arrival or on the order of a Minister or of an official. $^{15}$

Calwell did not get to capitalise on this vindication of his legislation. Eleven days before the judgment in Koon Wing Lau came down, the Chifley Government lost power. The incoming Minister for Immigration in the Liberal Government, Harold Holt, took a more accommodating approach to the groups targeted by Calwell and accepted the refugees still in Australia as a 'wartime legacy'. ${ }^{16}$ Calwell's strengthening of the Commonwealth's deportation power in fact went further than his successors needed. Neither the War-Time Refugees Removal Act 1949 nor the Aliens Deportation Act 1948 was used by Holt or later by Alexander Downer, senior. They relied on the deportation powers in the Immigration Act.

\section{The long reach of the deportation power in Australian law}

Calwell's moves to shore up the deportation power in immigration legislation had two lasting effects. The first arose from his insistence that people who had the status of non-British aliens should be liable for deportation on the basis of poor character or conduct no matter how long they had been settled in Australia. This principle, inscribed in the Aliens Deportation Act 1948, was incorporated into the Migration Act 1958, the legislation that still forms the basis of Australia's immigration policy. As we will see later in this chapter, the principle lives on today.

For the moment, it is instructive to touch on one case from 1961 - that of Antonio Panozzo. He arrived in Australia from Italy in 1952 with his wife and infant son as part of the postwar immigration program. Panozzo struggled to make good during his first decade in the country and, on several occasions in 1959 and 
1960, he was convicted of earning income from premises used for prostitution-namely, the back room of his shop and his house in Carlton, Melbourne. After serving his sentence, Panozzo and his family moved into a new house. They seemed to be rebuilding their lives when, nine months later, Panozzo was summoned to a deportation hearing because he was a non-British alien who had engaged in conduct that indicated that he 'should not be allowed to stay in the country'. ${ }^{17}$ The hearing, held before Commissioner F. R. B. Martin, was farcical in that it focused entirely on the respective roles of the commissioner and the minister in dealing with Panozzo's convictions. Panozzo's pleas that he was remorseful and had reformed, supported by his wife and his priest, were totally ignored. The hearing reduced his life in Australia to the rude fact of his convictions, casting a shadow over his entire existence in the country.

As Chief Justice Latham concluded in the Koon Wing Lau case, the Minister for Immigration could use any one of a range of criteria to issue a deportation order. In this case, Panozzo was deported because the minister concurred with the commissioner that Panozzo's convictions proved that his conduct was such that he should not be allowed to stay. The fate of Panozzo's wife and son is a blank spot in the history of deportation. Mrs Panozzo told the commissioner she was committed to her new country and did not wish to leave if her husband were deported, but it is not clear from archival records whether or not the family left with Panozzo.

The second of Calwell's changes that resonates with more recent times was his use of the term 'removal' in the War-Time Refugees Removal Act 1949, instead of 'deportation', as used in the Aliens Deportation Act 1948 or, 10 years later, the Immigration Act. 'Deportation' implied a legal process, typically the issuing of a formal deportation order and a hearing before a court, tribunal or commissioner. 'Removal' on the other hand suggested that procedures before any court, tribunal or commissioner could be dispensed with. Under the act, wartime refugees were simply to be 'removed' from the country because they had stayed on after the war ended; they would have no opportunity to put their case to stay in any hearing.

Calwell's scheme refused to countenance that individuals might have reasons to stay. His attitude to those who sought to stay was summed up in his characterisation of those people as 'a recalcitrant minority' ${ }^{18}$ This characterisation recalled John Leckie's justification for mass deportation after World War I because it implied that the people concerned had abused Australia's hospitality by stubbornly overstaying their welcome. Calwell, however, did not look to the past. He failed to recognise that exemptions to deportation had been made without detracting from overall immigration controls. For example, the exemption categories won by the Pacific Islanders were relevant to wartime refugees with locally born spouses, but Calwell feared that any exemption would open the 
floodgates. He was determined to hurry the wartime refugees on by the expeditious process of removal.

The War-Time Refugees Removal Act was shelved after the government changed in 1949, and it slipped into obscurity. Fifty years later, however, 'removal' began to be revived. This was no conscious act of remembrance or recovery, but it did begin with another government trying to dispense with deportation hearings, reviews and processes.

\section{Mandatory deportation and removal}

In 1989, the Hawke Labor Government was in its third term and was concerned with the increasing number of visa overstayers. The growing unemployment rate and fears about overstayers working illegally heightened its concerns. The Minister for Immigration, Robert Ray, introduced a draconian law for the 'mandatory deportation of illegal entrants', targeting visa overstayers: 'they are liable to be deported mandatorily', Ray stated, and his justification for the law resonated once again with the notion of Australia's abused hospitality. 'Those who choose to stay and impose themselves on Australia's generosity will feel the full weight of its laws,' he warned. ${ }^{19}$ There was, however, no indication that the minister was aware of the earlier statements he echoed, and the mandatory deportation policy failed to make allowance for even the exemption categories that the Pacific Islanders had won.

Mandatory deportation applied to visa overstayers no matter how long they had been in Australia. Their pasts in the country counted for naught against the fact that they had overstayed their visas. Labor Senator Jim McKiernan made clear that the law applied even to well-settled individuals and families: 'in some instances they will be leaving behind a home in some sort of fire sale', he told Parliament. 'Furniture and other possessions will have to be disposed of... There are also the difficulties associated with children's education. ${ }^{20}$

Like Calwell's legislation, the Labor Government's hardline measure in 1989 was not fully implemented, so community protests did not gather steam. Among other things, the government's focus shifted in 1989 to the reappearance of 'boat people' on Australia's shores and to the large number of Chinese students in Australia promised sanctuary after the crushing of the Tiananmen Square protests on 4 June 1989. Nonetheless, the law about the 'mandatory deportation of illegal entrants' signalled a return to the idea that people should be removed from the country if they had no permission to stay and that this should occur as a simple matter of course, not as a result of a deportation decision against an individual after a hearing or review of their case.

In 1992, 'mandatory deportation' was superseded by 'removal' under Section 189 of the Migration Act 1958 and the act set out a fully fledged removal system directed against people in Australia without authority. This required that any 
people lacking a valid visa should remove themselves from the country or face being put in detention and removed by the Immigration Department. A parliamentary committee described the nature of the new system:

Unlike the power to order deportation, which is discretionary, removal is an automatic consequence for every unlawful non-citizen. Non-citizens who do not hold a valid visa must be detained under s.189 of the Act and removed (ie expelled) under s.198. Mandatory removal was introduced to simplify the procedures for removing persons who had no legal authority to remain in Australia. It reinforces the principle that such persons have 'no right to stay in the country' ${ }^{21}$

The final phrase quotes an instruction from the Immigration Department to its officers as to who they should remove from the country. ${ }^{22}$ Under the removal system, officers were required to check the visa status of non-citizens in the community to identify unlawful non-citizens (such identifications were called 'locations') and to see that any unlawful non-citizen was removed from the country via a 'monitored removal', 'supervised removal' or plain 'removal'.

The removal system led to a significant increase in the number of enforced departures. In the 1980s, approximately 1000 deportations occurred from Australia each year. Since 2000, the Immigration Department has recorded more than 10000 removals annually. ${ }^{23}$

There have been a number of controversial cases under the removal system. These include the removal to China in 1997 of a heavily pregnant woman whose near-term baby was aborted a week after her arrival, the threatened removal of a Somali man in 1998 and, most prominently, the threatened removal of Cornelia Rau to Germany in 2004-05 and the unlawful removal of an Australian citizen, Vivian Alvarez, to the Philippines in 2001 - a scandal that came to light only in 2005 after the Cornelia Rau case. ${ }^{24}$

There are three features of the removal system that merit comment. The first is the parallel between the current system and Calwell's earlier legislation, whereby there is no decision on an individual's particular circumstances but they face removal simply by virtue of being in the country beyond their permitted stay. A recent report by the Refugee Health Research Centre in Melbourne has summarised how this can lead to individuals' circumstances being neglected:

$[\mathrm{T}]$ here is no formal decision to remove someone. This means there is no pre-removal assessment of the whole of an individual's situation, including medical issues or issues regarding children and family ties, that may bring to light significant reasons to delay or reconsider removal. $^{25}$ 
The Vivian Alvarez scandal provided a stark illustration of these problems. An Australian citizen of Filipino background, Alvarez had suffered mental health problems for five years before she went missing in February 2001, having failed to pick up her son from child care in Brisbane. She was found, although not identified, six weeks later in Lismore, New South Wales, and was hospitalised for physical and mental health problems. She was in no position to present evidence of citizenship status in Australia and, when immigration officials were called in on 3 May 2001, they acted on the assumption that she was an unlawful non-citizen. Alvarez had no hearing before an independent authority and no legal representation. The traditional function of a deportation hearing - primarily to verify the identity and citizenship status of the person - does not occur under the removal system. Instead, officials concentrated on making the arrangements for Alvarez's removal, which occurred on 20 July 2001. What happened to her was fully revealed only in 2005 when she was located in a hospice in the Philippines and an inquiry into her case was launched. The investigator, Neil Comrie, noted that ' $[\mathrm{t}]$ here is no record of an actual decision to remove Vivian - if one was made' and criticised the perfunctory medical check certifying her as fit to travel. Comrie concluded that, quite apart from being unlawful because she was an Australian citizen, Alvarez's 'removal was effected with undue haste and without adequate consideration of her welfare' ${ }^{26}$

The second point about today's removal system is that it turns its back on knowledge available from earlier decisions on deportation cases. Under administrative law reforms in the 1970s, deportation decisions became reviewable by the Administrative Appeals Tribunal. The tribunal published its decisions and built up a valuable corpus of knowledge about how to ensure that deportation procedures were fair and flexible. For example, in the case of Drago Sajatovic in 1985, it was prepared to endorse the minister's decision to issue a deportation order on the grounds of his criminal record, but noted that his country of birth, Yugoslavia, was not facilitating his return after virtually a lifetime away. The tribunal noted that it is undesirable that the execution of a deportation order should be delayed for any considerable time; circumstances relevant to the appropriateness of the deportation may have changed in the meantime'. It therefore recommended that the deportation order be revoked. If it subsequently became possible to carry out the deportation, the tribunal concluded, the case should be reconsidered in the light of all the circumstances at that time. ${ }^{27}$

In the case of John Kirakos five years later, in 1990, the tribunal followed a similar line. It noted that he had already been held in prison for 10 months after the expiration of his sentence while immigration officials sought to finalise his deportation. Kirakos was born in Syria to Armenian refugees from Turkey, but had no civil registration in Syria, in the absence of which Syrian officials refused to accept him. Noting the long delay already, the tribunal set a deadline of a 
further four months for officials to arrange for his departure. If they were unable to do this, the tribunal recommended that the deportation order should be revoked, rather than Kirakos continuing to languish in incarceration. ${ }^{28}$ These decisions evince a far more flexible approach than is available under the removal system whereby individuals can be held for indefinite periods in immigration detention while immigration officials make the arrangements for removal.

The Administrative Appeals Tribunal developed a strong position in reviewing cases involving long-term Australian residents facing deportation. The key case was the drawn-out saga of Luigi Pochi, who was issued with a deportation order in 1978 after serving a year in prison for his part in cultivating marijuana. Pochi had been in Australia for nearly 20 years, was married and had three Australian-born children. In these circumstances, the tribunal's president, Gerard Brennan, found that a compelling case was required to proceed with deportation:

When an alien has been resident in this country for many years, when his roots are deep in Australia and the ties which bind him to Australia are strong, a clear case will be required to persuade the decision-maker that it is in the best interests of Australia to banish him from our shores. ${ }^{29}$

Pochi's case dragged on through the courts for another four years, but, ultimately, he was not deported. In 1983, the Hawke Government in its first term tackled the issue of long-term residents facing deportation after a criminal conviction. It introduced legislative amendments whereby the liability to deportation on grounds of criminal conviction ceased after 10 years' residence in Australia (excluding prison time) and it introduced a specific criminal deportation policy. ${ }^{30}$

The final point to note about the removal system is that it has turned the clock back to the days when individuals could be expelled on the grounds of criminal conviction despite having lived in the country for decades. The 10-year rule has been rendered ineffective by means of the Migration Legislation Amendment (Strengthening of Provisions Relating to Character and Conduct) Act 1998, which was introduced by Philip Ruddock. Its provisions allow the Minister for Immigration to cancel a person's visa regardless of how long that person has lived in Australia and disallows reviews to the Administrative Appeals Tribunal in cases where the minister personally has cancelled the visa. There are no hearings on such matters - the cancellation is made on the recommendation of a departmental briefing paper. This new power came to supersede the traditional criminal deportation process, which fell into disuse. ${ }^{31}$

Between 1 July 2002 and 30 June 2005, the Howard Government removed 233 permanent residents on the grounds that they had been sentenced to imprisonment of one year or more and were therefore deemed to be of bad character. ${ }^{32}$ Many had lived in Australia since childhood and were removed to 
places they barely remembered. The guidelines for cancelling visas gave little weight to length of residence and ties to Australia were downgraded.

The starkest case was that of Stefan Nystrom. He was born in Sweden when his mother visited there from her new home in Australia. Nystrom himself arrived in Australia as a twenty-seven-day-old baby, and grew up and was educated in Australia. He did not leave the country until he was removed as a thirty-three-year-old after his permanent residency was cancelled because of his criminal convictions. Nystrom was sent back to Sweden although he spoke no Swedish and had only distant relatives there. He told a journalist who spoke to him there that 'I am Aussie, I don't give a stuff about Sweden, I never have and I never will' ${ }^{33}$ The High Court of Australia had been called on to decide Nystrom's case and it affirmed the minister's power to remove him and other long-term permanent residents. ${ }^{34}$ Others in a similar situation included Tayfun Ayan, removed to Turkey despite having arrived in Australia as a six-month-old child and being, in the words of a Federal Court judge, 'an Australian...in every respect, except citizenship', and Toni Morgani, removed to Italy in 2003 notwithstanding that, as representatives of the Italian Government observed, 'culturally, psychologically, educationally, he's Australian'. ${ }^{35}$

\section{Conclusion}

Today's removal system contains the two key elements of Calwell's deportation regime after World War II. Like Calwell's Aliens Deportation Act 1948, the removal system gives the minister imposing powers to expel people with alien status on the grounds of character and conduct, regardless of their length of residence in the country and local ties. And, like Calwell's War-Time Refugees Removal Act 1949, today's removal system replaces traditional deportation hearings and decisions with automatic action against people in the country without valid documentation.

Today's removal policies were made with no consciousness of Calwell's legislation, which had long been forgotten. Nor do today's policies pay attention to lessons set down by the Administrative Appeals Tribunal in its deportation decisions in the 1970s and 1980s, as we have observed. The Department of Immigration asserts that Australia's policies are forward looking. In 2004, the department claimed that it had achieved 'world's best practice' in identifying and dealing with people without a visa and that the rest of the world was trying to catch up. ${ }^{36}$

There is some truth to this claim. Other countries have implemented removal systems that seek to minimise legal procedures and achieve expeditious expulsions of undocumented immigrants. The United States introduced 'expedited removal' in 1996 in the Illegal Immigration Reform and Immigrant Responsibility Act. Canada completely overhauled its immigration enforcement 
bodies in 2003 to provide more vigorous execution of removals. And in the United Kingdom officials have established a 'tipping point' target, whereby the number of asylum-seekers being removed from the country exceeds the number of rejected asylum applications. ${ }^{37}$

While these international similarities are important, we have seen that there is a distinct national lineage underpinning Australia's removal system today. This lineage is grounded in the imposing powers of the Commonwealth Government, endorsed time and again by the High Court, to control the entry, stay and departure of people with alien status, now usually called non-citizens. Calwell drew on these powers in strengthening deportation laws after the $O^{\prime}$ Keefe defeat when he reinforced the legal framework for deporting aliens even after decades in the country and for removing individuals in the country without valid documentation. These powers were hardly used at the time, but elements from Calwell's legislation survived in the Migration Act 1958, and in 1961 Antonio Panozzo felt the brunt of the minister's power to deport an alien on the basis of his bad character. In 1989, Ruddock strengthened the character test in the Migration Act and used it to remove hundreds of non-citizens with criminal convictions. He did this regardless of the fact that many had lived in Australia virtually their whole lives.

Under Ruddock, the removal system was at its most unrelenting. In 2002-03, nearly 14000 people were removed from the country: rejected asylum-seekers, visa overstayers, illegal workers and 'bad character' criminals. ${ }^{38}$ The nether side of this heavy-handed action was the Cornelia Rau and Vivian Alvarez scandals and more than 200 individuals held in immigration detention centres for more than two years, whose cases were investigated by the Commonwealth Ombudsman after 2005. Ruddock's rigid application of the removal system had no time for the principles of flexibility that the Administrative Appeals Tribunal worked out when it dealt with deportation cases involving inordinate delays. The tribunal's assumption in such cases was that it was in no-one's interest to leave the individuals concerned languishing in limbo for years awaiting deportation. The position was principled and practical, but it was forgotten under Ruddock's regime of being tough on crime and border control.

In the face of protests about particular cases, policy makers have justified deportation with the argument that the regime serves to maintain immigration controls and keep the floodgates shut, and to uphold law and order and guarantee Australia's national security. As we have seen, these justifications have been accompanied by the argument that deportation is directed against those who have abused Australia's generosity by overstaying their welcome or endangering national security or law and order (see Chapter 3 for further discussion of the notion of Australian generosity). A range of policy makers over the years has invoked this argument without awareness of one another. Nor have policy 
makers been aware of exemption categories accepted in earlier times-for example, those exemptions won by the first group to face mass deportation: Pacific Islanders in Australia at the time of Federation. Policy makers have not viewed deportation as an area of decision making in its own right and with its own history, but as a footnote or follow-up to policies on immigration control, law and order and national security. Consequently, no lasting policy has been developed to take individuals' circumstances into account or to examine factors militating against deportation. Today, non-citizens without a valid visa face automatic removal from Australia without any decision on their particular circumstances.

Pacific Islanders were the first group to face mass deportation from Australia but they won a series of exemption categories. Unfortunately, these categories were forgotten afterwards. The dominant factor driving policy makers has been maintaining immigration controls, especially on non-European migration, and not allowing exemptions that will weaken controls. In addition, mass deportations after the two world wars were driven by hysteria about national security and wartime animosity. At these times, policy makers ordered the mass expulsion of people born in countries that had become Australia's wartime enemies or were descended from citizens of those countries. This happened regardless of individuals' pasts in Australia and of their prospects in the destination country. An Australian embarkation officer who raised concerns in 1946 about atrocious conditions on a deportation ship to Japan was told that 'the responsibility of the Australian army would cease at the gangway', reflecting the official desire to get individuals out of sight and mind. ${ }^{39}$ Australia's Japanese community was deported en masse after World War II. No exemptions were allowed and no traces of their presence were preserved.

Policy makers today could improve Australia's deportation practices by developing a policy that is not merely an afterthought to rigidly upholding immigration controls. Such a policy would insist on careful decision making on each deportation case and would allow exemptions based on individuals' pasts in the country and on their likely fate in destination countries. Today, only the Minister for Immigration can grant an exemption along these lines in exceptional circumstances. It is time to make these exemption categories the basis of a specific deportation policy that focuses on individuals' circumstances.

\section{Endnotes}

1 J. A. Stalking, Note, 23 December 1910, National Archives of Australia [hereafter NAA], A1, 1912/11862.

2 Robtelmes vs Brenan [1906], 4 CLR 395, p. 420. For a more detailed discussion of this and other cases referred to in this article, see my book: Nicholls, Glenn 2007, Deported: A history of forced departures from Australia, UNSW Press, Sydney.

3 Commonwealth Parliamentary Debates [hereafter CPD], vol. 88, 10 July 1919, p. 10636. 
4 Fischer, Gerhard 2000, 'Integration, "negative integration", disintegration: the destruction of the German-Australian community during the First World War', in Kay Saunders and Roger Daniels (eds), Alien Justice: Wartime internment in Australia and North America, University of Queensland Press, St Lucia, pp. 1-27.

5 Dugdale, Joan 1991, Struggle of Memory, University of Queensland Press, St Lucia. A recent novel by Linda Jaivan (2006, The Infernal Optimist, Fourth Estate, Pymble) concerns a deportation case but focuses mainly on conditions in one of Australia's immigration detention centres.

6 Corris, Peter 1972, “'White Australia" in action: the repatriation of Pacific Islanders from Queensland', Historical Studies, vol. 15, no. 58, pp. 237-50.

7 Moore, Clive and Mercer, P. M. 1978, 'The forgotten people: Australia's immigrant Melanesians', Meanjin, vol. 37, no. 1, pp. 98-108.

8 Human Rights and Equal Opportunity Commission 1992, The Call for Recognition: A report on the situation of Australian South Sea Islanders, Human Rights and Equal Opportunity Commission, Sydney, p. 91.

9 CPD, Representatives, vol. 30, 12 December 1905, p. 6673.

10 Tavan, Gwenda 2005, The Long, Slow Death of White Australia, Scribe, Melbourne, p. 62.

11 Arthur Calwell, 22 October 1948, Deportation of Aliens Bill, Second Reading, House of Representatives; and Senator Armstrong, 2 December 1948, Second Reading, Senate, NAA, A446, 1964/46109.

12 Neumann, Klaus 2006, 'Guarding the flood gates: the removal of non-Europeans, 1945-1949', in Martin Crotty and David Roberts (eds), The Great Mistakes of Australian History, UNSW Press, Sydney, pp. 186-202.

$13 C P D$, vol. 201, 9 February 1949, p. 66.

14 J. B. Tait, Memorandum of counsel, 25 May 1949, NAA, A432, 1949/472.

15 Koon Wing Lau vs Calwell [1949], 80 CLR 533, pp. 561-2.

16 Frame, Tom 2005, The Life and Death of Harold Holt, Allen \& Unwin, Sydney, p. 67.

17 Section 14 of the Migration Act 1958 empowered the Minister to order the deportation of an alien whose conduct 'has been such that he should not be allowed to remain in Australia'. (The Migration Act 1958: An investigation by a Commissioner Pursant to Section 14 of the Act of the Case of Antonio Panozzo, Transcript of Proceedings p. 10A, NAA A446 1961/66437).

18 King, John 2005, "The creation of a "recalcitrant minority": a case-study of the Chinese New Guinea wartime refugees', Journal of the Royal Australian Historical Society, vol. 91, no. 1.

19 Ray, Robert 1989, 'Minister Ray hails start of new era in immigration', Ministerial Document Service, 18 December 1989, p. 4238.

20 CPD, Senate, vol. 140, 10 October 1990, p. 2833.

21 Parliament of the Commonwealth of Australia 1998, Deportation of Non-Citizen Criminals, Joint Standing Committee on Migration, Canberra, p. 71, para. 7.1.

22 Migration Series Instruction 5, 31 October 1996.

23 Parliament of Australia 1990, First Report: Illegal entrants in Australia-balancing control and compassion, Joint Standing Committee on Migration Regulations, p. 23, Table T5; Department of Immigration and Multicultural Affairs 2001, Annual Report 2000-01, Canberra,

<www.immi.gov.au/about/reports/annual/2000-01/report19.htm>; Department of Immigration and Multicultural and Indigenous Affairs 2004, Annual Report 2003-04, Canberra, p. 89; Department of Immigration and Multicultural and Indigenous Affairs 2005, Annual Report 2004-05, Canberra, p. 124.

24 Senate Legal and Constitutional References Committee 2000, A Sanctuary Under Review: An examination of Australia's refugee and humanitarian determination process, June, Senate Printing Unit, Canberra, pp. 203-35, 268-96; Palmer, M. 2005, Inquiry into the Circumstances of the Immigration Detention of Cornelia Rau: Report, 6 July 2005, Commonwealth of Australia, Canberra; Comrie, Neil 2005, Inquiry into the Circumstances of the Vivian Alvarez Matter, Commonwealth Ombudsman, Canberra.

25 Sampson, Robyn, Correa-Velez, Ignacio and Mitchell, Grant 2007, Removing Seriously Ill Asylum Seekers from Australia, Refugee Health Research Centre, Melbourne, p. 51.

26 Comrie, Inquiry into the Circumstances of the Vivian Alvarez Matter, pp. xiii, 60.

27 Re: Drago Sajatovic and Minister for Immigration and Ethnic Affairs, Administrative Appeals Tribunal Decision No. V85/275.

28 Re: John Arseine Kirakos and Minister for Immigration, Local Government and Ethnic Affairs, Administrative Appeals Tribunal Decision No. V90/83. 
29 Re Luigi Pochi and the Minister for Immigration and Ethnic Affairs [1979], 36 FLR 482, 491.

30 CPD, Representatives, vol. 131, 4 May 1983, pp. 166-9.

31 Turner, Ray 2002, 'Ridding the country of "bad aliens": the operation of the character and conduct provisions in the Migration Act 1958', Immigration Review, vol. 6, pp. 7-10.

32 Senate Legal and Constitutional References Committee 2006, Administration and Operation of the Migration Act 1958, Senate Printing Unit, Canberra, p. 293.

33 Medew, Julia 2007, 'Aussie rapist deported to Sweden on a technicality to do even harder time', Age, 24 February 2007.

34 Minister for Immigration and Multicultural and Indigenous Affairs vs Nystrom [2006], HCA 50, 8 November 2006.

35 Ayan vs Minister for Immigration and Multicultural and Indigenous Affairs [2003], 126 FCR 152, 154. Panichi, James and Pascucci, Maurizio 2003, 'Arrivederci, padre: an Aussie becomes an alien', Age, 17 November 2003.

36 Department of Immigration and Multicultural and Indigenous Affairs 2004, Tracking of visa overstayers world's best practice, Press statement 074/2004, Canberra, 19 July 2004.

37 Konet, Dawn and Batalova, Jeanne 2007, 'Spotlight on immigration enforcement in the United States', Migration Information Source, Migration Policy Institute, 22 March 2007; Fraser, Sheila 2003, Citizenship and immigration - Canada faces a growing backlog of removal orders and does not know how well its immigration border controls are working, Media release by the Auditor-General of Canada, 8 April 2003, Ottawa, <www.oag-bvg.gc.ca/domino/media.nsf/html/20030405pr_e.html>; United Kingdom Border and Immigration Agency n.d., Our Targets, London,

$<$ www.ind.homeoffice.gov.uk/aboutus/ourtargets>; United Kingdom House of Commons Home Affairs Committee 2003, Asylum Removals, Stationery Office, London.

38 Department of Immigration and Multicultural and Indigenous Affairs 2003, Annual Report 2002-03, Canberra, <www.immi.gov.au/about/reports/annual/2002-03/report34.htm>

39 Nagata, Yuriko 1996, Unwanted Aliens: Japanese internment in Australia, University of Queensland Press, St Lucia, p. 204. 